\title{
What Should Be Considered for Acceptance Mobile Payment: An Investigation of the Factors Affecting of the Intention to Use System Services T-Cash
}

\author{
Riyan Rizkyandy*, Djoko Budiyanto Setyohadi, Suyoto \\ Universitas Atma Jaya Yogyakarta, Yogyakarta, 55281, Indonesia
}

\begin{tabular}{l} 
A R T I C L E I N F O \\
\hline Article history: \\
Received: 01 March, 2018 \\
Accepted: 28 March, 2018 \\
Online: 25 April, 2018 \\
\hline
\end{tabular}

Keywords:

Mobile Payment

E-money

T-cash

Technology Acceptance Model

\begin{abstract}
A B S T R A C T
E-Money mobile payments, also called digital money, are electronic payments, payment transactions using an Internet network integrated with NFC-enabled smartphones and prepaid cards. In Indonesia not only banks that issue e-money products, telecom operators from Telkomsel also issued an e-money product called T-cash. T-cash is a new innovation of electronic money presented by Telkomsel. The purpose of this study was to check the effect of responsiveness, smartness, perceived ease of use, perceived usefulness, social influence, and security against the intention to use T-cash. The data used in this study include primary and secondary data. Respondents in this study are users of T-cash products in Yogyakarta as many as 115 respondents. While the data were collected by using the questionnaire to then be analyzed using the amos analysis technique 22.0. The results of the analysis prove that two characteristics of technology, responsiveness and smartness have a significant effect on perceived usefulness. Ease of use has a significant effect on perceived usefulness. Ease of use, usefulness and security have a significant effect on intention to use. The higher the level of responsiveness, smartness, ease of use, perceived usefulness and security will also increase the use of T-cash social influence factors have no effect on intention to use.
\end{abstract}

\section{Introduction}

The current payment system has evolved and has evolved to abandon the old way and switch to mobile devices (m-device) now known as mobile payment (m-payment) [1]. The new payment system is the result of the development of information and communication technology in the field of economic transactions between companies and customers [2]. This payment system emerges as one way to solve certain problems related to the handling of the circulation of cash. This payment system ensures flexibility for small purchases and instant payments, enhances security and protection against fraud and other forms of crime, the emergence of e-commerce on the internet and online payments $[3,4]$. The current payment system should also take into account social influencing factors that will influence consumers to use mobile payment services $[5,6]$.

E-money or electronic money is the amount of money a person keeps in an electronic medium that is officially accepted as a

${ }^{*}$ Corresponding Author: Riyan Rizkyandy, Universitas Atma Jaya Yogyakarta, Yogyakarta, Indonesia. Email: rizkyandyriyan@gmail.com means of payment [7]. These payments are used for small-value transactions such as parking and public transport payments that are now beginning to use electronic cards containing e-money. And large-value transactions such as payments on the sale of goods in online shopping and transactions between other business actors [8].

In Indonesia one of the companies offering NFC based mobile payment is T-cash. T-cash is one of the services offered by Telkomsel. Telkomsel which started its business from cellular operator services then expanded its business network by offering T-cash mobile payment service. Telkomsel has obtained a license from Bank Indonesia as an electronic money service provider. Tcash can be used by all Telkomsel subscribers, either postpaid or prepaid.

Telkomsel introduced T-cash as a new generation of electronic money services as well as mobile payments. T-cash comes with innovations that will give customers and merchants an exciting new experience in making payments via mobile phones. T-cash is a product of e-money that facilitates transactions to various circles 
of society, including communities that have not been served by an authorized financial institution. T-cash was first introduced in 2015, the use of the T-cash service is easy, simply by enabling and sticking the NFC T-cash sticker to the phone [9].

With the number of e-money products in Indonesia emerging and competing, one of them is T-cash shows that technology is growing and innovation payment using e-money increasingly popular with the public. People's attention to e-money is increasingly high cause a lot of various e-money products issued by banks and other companies in Indonesia. People feel a lot of benefits and assume that using e-money products can improve or improve their social status. And some people think that new technology will only make them difficult because they are used to and comfortable with the payment of the old way. Therefore, the authors are interested to examine the issue with the title "What Should Be Considered for Acceptance Mobile Payment: An Investigation of the Factors Affecting of the Intent to Use System Services T-Cash".

Contribution in this research is social influence factor, security factor and two factor of technology characteristic that is responsiveness and smartness as an important variable that can influence the consumer to use t-cash. The contribution is important given the issue of security using electronic money greatly affects the intention to use mobile e-money payments. And in this research can also be explained that the factors responsiveness, smartness, perceived ease of use, perceived usefulness, social influence, and security are factors that may affect the intention to use e-money.

\section{Hypothesis Development}

\subsection{Technology Characteristics}

In human-computer interaction (HCI) responsiveness is an important factor because users want a responsive mobile payment system in accordance with what users expect. And using the payment system makes users look smart [10]. In [11], it is explained that two characteristics of responsiveness and smartness technologies have a significant impact on perceived usefulness.

H1: Responsiveness has a positive and significant impact on the perceived usefulness of mobile t-cash (e-money) payment system service in Yogyakarta.

H2: Smartness has a positive and significant impact on the perceived usefulness of mobile t-cash (e-money) payment system service in Yogyakarta.

\subsection{TAM (Technology Acceptance Model)}

In [12], it states that the Technology Acceptance Model (TAM) was developed by Davis in 1986 [13], which originated from the theory of Fishbein and Ajzen (1975) Theory of Reasoned. TAM provides a theoretical basis for knowing what factors influence the acceptance of a technology in an organization [14]. And in [15], This study examines user acceptance and use of mobile payments, focusing on mobile ticket technology applied in the context of public transport. The results show that the intention to use technology is influenced by perceived usefulness, Ease of Use and Security of that technology. In addition, perceived usefulness is simultaneously affected by ease of use.
H3: Perceived ease of use has a positive and significant impact on the perceived usefulness of mobile t-cash (e-money) payment system service in Yogyakarta.

H4: Perceived ease of use has a positive and significant impact on the intention to use mobile t-cash (e-money) mobile payment system service in Yogyakarta.

H5: Perceived usefulness has a positive and significant impact on the intention to use mobile t-cash (e-money) payment system service in Yogyakarta.

\subsection{Social Influences}

According to [16,17], social influencing factors are how a group or environmental factors can influence a person's behavior decisions. Social influence is a reflection of the results of communication and interaction with others so that with the occurrence of these influences can change a person's attitude or behavior. In [18], about the intent and behavior to use e-learning, those social factors are more important than usability perceptions and perceptions of ease of use, because social factors that influence students to use e-learning come from seniors as well as instructors, and lecturers are also a factor successful implementation of elearning. In [19], explains Subjective Norm His influence can come from the views and roles of friends, peers, families, and superiors. Subjective norms have an important role in the study of the adoption of new technologies.

H6: Social influencing factors have a positive and significant impact on the intention to use mobile t-cash (e-money) payment system service in Yogyakarta.

\subsection{Security}

In [20], explains security is an important factor in shaping consumer confidence. The perception of security is the consumer's trust in the service user can control and maintain personal data as well as transaction data from abuse by an irresponsible person. In the study [21], found that security had a significant positive effect on online purchasing decisions. Security becomes one of the important factors because the payment transaction is done through internet network.

H7: Security has a positive and significant impact on the intention to use mobile t-cash (e-money) payment system service in Yogyakarta.

The framework underlying this research can be shown in Figure 1:

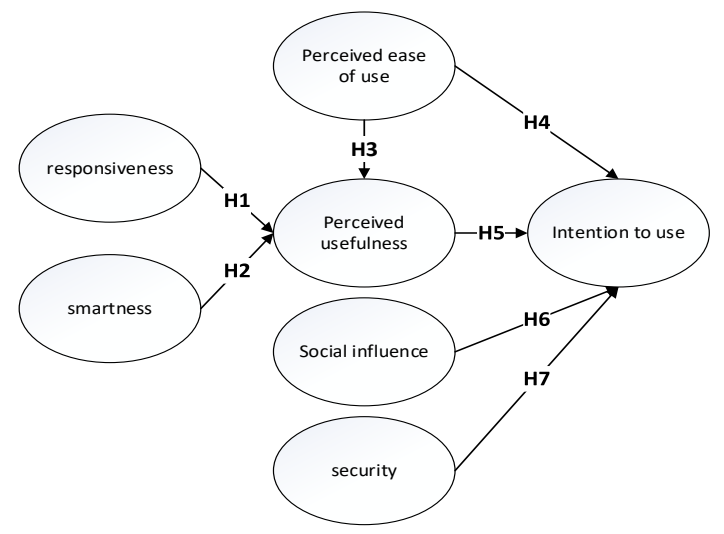

Fig 1: Research Model and Hypothesis 


\section{Method}

The population in this research is Telkomsel subscribers who use $\mathrm{T}$-cash service or who have never used $\mathrm{T}$-cash respondents have unlimited nature because the number and characteristics of research respondents are not known for certain. The sampling technique used in this research is the nonprobability sampling technique. The respondents of this research are all Telkomsel subscribers who use T-cash who have access and have made Tcash mobile payment transaction in Yogyakarta.

The sample size plays an important role in the estimation and interpretation of results. In other structural methods, the sample size becomes the basis for the estimation of sampling error [22]. The sample size guidelines are 5-10 times the estimated number of parameters, the samples were taken in this study were 115 respondents (23 indicators $x$ 5) [23,24].

In the questionnaire, there are two parts, the respondent's demographic information section, and 23 questions representing the factors in this study. Measurement of variables using Likert scale 1-5. List of questions can be seen in table 1 .

Table 1: Questionnaire

\begin{tabular}{|c|c|c|}
\hline Factor & Item & Question \\
\hline \multirow{3}{*}{$\begin{array}{l}\text { Responsiveness } \\
\text { (RES) }\end{array}$} & RES1 & $\begin{array}{l}\text { T-Cash mobile payment will } \\
\text { offer prompt service to me. }\end{array}$ \\
\hline & RES2 & $\begin{array}{l}\text { T-Cash mobile payment has } \\
\text { willingness to help me. }\end{array}$ \\
\hline & RES3 & $\begin{array}{l}\text { T-Cash mobile payment gives } \\
\text { me individual attention. }\end{array}$ \\
\hline \multirow{3}{*}{$\begin{array}{l}\text { Smartness } \\
\text { (SMA) }\end{array}$} & SMA1 & $\begin{array}{l}\text { T-Cash mobile payment is } \\
\text { intelligent. }\end{array}$ \\
\hline & SMA2 & T-Cash mobile payment is smart. \\
\hline & SMA3 & $\begin{array}{l}\text { T-Cash mobile payment makes } \\
\text { me look smart. }\end{array}$ \\
\hline \multirow{3}{*}{$\begin{array}{l}\text { Perceive Ease } \\
\text { of Use } \\
\text { (PEOU) }\end{array}$} & PEOU1 & $\begin{array}{l}\text { Learning to operate an T-Cash } \\
\text { mobile payment system would } \\
\text { be easy for me. }\end{array}$ \\
\hline & PEOU2 & $\begin{array}{l}\text { I would find an T-Cash mobile } \\
\text { payment system easy to use. }\end{array}$ \\
\hline & PEOU3 & $\begin{array}{l}\text { I think it is easy to use an T- } \\
\text { Cash mobile payment system. }\end{array}$ \\
\hline \multirow{3}{*}{$\begin{array}{l}\text { Perceive } \\
\text { Usefulness } \\
\quad(\mathrm{PU})\end{array}$} & PU1 & $\begin{array}{l}\text { Using T-Cash mobile payment } \\
\text { system in my finance related job } \\
\text { would enable me to accomplish } \\
\text { tasks more quickly. }\end{array}$ \\
\hline & PU2 & $\begin{array}{l}\text { Using T-Cash mobile payment } \\
\text { would enhance the effectiveness } \\
\text { of my finance related job. }\end{array}$ \\
\hline & PU3 & $\begin{array}{l}\text { I would find T-Cash mobile } \\
\text { payment system useful in my } \\
\text { finance job. }\end{array}$ \\
\hline \multirow{3}{*}{$\begin{array}{l}\text { Social } \\
\text { Influence } \\
\quad(\mathrm{SI})\end{array}$} & SI1 & $\begin{array}{l}\text { Friend's suggestions and } \\
\text { recommendations will affect } \\
\text { my decision to use T-Cash }\end{array}$ \\
\hline & $\mathrm{SI} 2$ & $\begin{array}{l}\text { Family/relatives have influence } \\
\text { on my decision to use T-Cash }\end{array}$ \\
\hline & SI3 & $\begin{array}{l}\text { I will use T-Cash if my } \\
\text { colleagues use it }\end{array}$ \\
\hline
\end{tabular}

\begin{tabular}{|c|l|l|}
\hline \multirow{2}{*}{} & SI4 & $\begin{array}{l}\text { I will use T-Cash if the service is } \\
\text { widely used by people in } \\
\text { my community }\end{array}$ \\
\cline { 2 - 3 } & SI5 & $\begin{array}{l}\text { T-Cash will enable me to } \\
\text { improve my social status }\end{array}$ \\
\hline \multirow{4}{*}{$\begin{array}{c}\text { Security } \\
\text { (SEC) }\end{array}$} & SEC1 & $\begin{array}{l}\text { I think that purchasing through a } \\
\text { T-Cash mobile payment is } \\
\text { secure. }\end{array}$ \\
\cline { 2 - 3 } & SEC2 & $\begin{array}{l}\text { I feel secure entering my card } \\
\text { details for payment within the T- } \\
\text { Cash. }\end{array}$ \\
\cline { 2 - 3 } & SEC3 & $\begin{array}{l}\text { I find T-Cash mobile payment } \\
\text { services secure for conducting } \\
\text { my payment transactions. }\end{array}$ \\
\hline \multirow{2}{*}{$\begin{array}{c}\text { Intention to } \\
\text { Use (ITU) }\end{array}$} & ITU2 & $\begin{array}{l}\text { I intend to use the T-Cash } \\
\text { mobile payment system. }\end{array}$ \\
\cline { 2 - 3 } & ITU3 & $\begin{array}{l}\text { I predict I would continue using } \\
\text { the T-Cash mobile payment } \\
\text { system. }\end{array}$ \\
\cline { 2 - 3 } & $\begin{array}{l}\text { I plan to continue using the T- } \\
\text { Cash mobile payment system. }\end{array}$ \\
\hline
\end{tabular}

Table 2 summarizes the demographic characteristics of respondents. Age is divided into 3 groups, and the most dominant age is the age group of $20-25$ years of $67.0 \% .51 .3 \%$ were male and $48.7 \%$ were female. At the education level, there are 4 groups, namely SMP (junior high school), SMA (senior high school), S1 (undergraduate), S2 (postgraduate). which dominates the level of education $\mathrm{S} 1$ by $43.5 \%$. 55.7\% active transactions using T-cash and $44.3 \%$ inactive transactions using T-cash.

Table 2: Demographic of the Respondents

\begin{tabular}{|c|c|c|c|}
\hline \multicolumn{2}{|c|}{ Demographic } & Frequency & Percent $\%$ \\
\hline \multirow{3}{*}{ Age } & $<20$ years & 33 & 28.7 \\
\hline & 20-25 years & 75 & 67.0 \\
\hline & $>25$ years & 5 & 4.3 \\
\hline \multirow{2}{*}{ Gender } & Male & 59 & 51.3 \\
\hline & Female & 56 & 48.7 \\
\hline \multirow{4}{*}{$\begin{array}{l}\text { Level of } \\
\text { Education }\end{array}$} & SMP & 18 & 15.7 \\
\hline & SMA & 44 & 38.3 \\
\hline & $\mathrm{S} 1$ & 50 & 43.5 \\
\hline & $\mathrm{S} 2$ & 3 & 2.6 \\
\hline \multirow{2}{*}{$\begin{array}{l}\text { Active } \\
\text { Transaction } \\
\text { T-cash }\end{array}$} & Yes & 64 & 55.7 \\
\hline & No & 51 & 44.3 \\
\hline
\end{tabular}

\section{Results and Discussion}

\subsection{Measurement Model Assessment}

Assessing the goodness of fit is the primary goal in SEM to know to what extent the model is hypothesized "Fit" or matched the data sample $[22,25]$. The result of goodness of fit is shown in the data in table 3. Based on the Results in Table 3, it can be seen that the research model is approaching as a good fit model.

The result of CMIN / DF in this study 1,433 showed that the fit research model. The GFI value in this model is 0.823 . The value close to the recommended level $\geq 0.90$ shows the marginal fit 
research model. The RMSEA value of this study was 0.062 with the recommended value of $\leq 0.08$ this shows the fit research model. The AGFI value in this model is 0.711 . The value close to the recommended level $\geq 0.80$ shows the marginal fit research model. TLI value in this study is 0.941 with the recommended value of $\geq$ 0.90 it shows fit research model. The NFI value in this study was 0.829 closer to the recommended level $\geq 0.90$ showing the marginal fit research model. Based on the overall measurement of goodness of fit above indicates that the model proposed in this research is accepted.

Table 3: Assessing the Goodness of Fit

\begin{tabular}{|l|c|c|c|}
\hline $\begin{array}{c}\text { Goodness } \\
\text { of fit index }\end{array}$ & $\begin{array}{c}\text { Cut-off } \\
\text { value }\end{array}$ & $\begin{array}{c}\text { Reserach } \\
\text { Model }\end{array}$ & Model \\
\hline $\begin{array}{l}\text { Significant } \\
\text { probability }\end{array}$ & $\geq 0.05$ & 0.000 & Marginal \\
\hline RMSEA & $\leq 0.08$ & 0.062 & Fit \\
\hline GFI & $\geq 0.90$ & 0.823 & Marginal \\
\hline AGFI & $\geq 0.90$ & 0.711 & Marginal \\
\hline CMIN/DF & $\leq 2.0$ & 1.433 & Fit \\
\hline TLI & $\geq 0.90$ & 0.929 & Fit \\
\hline CFI & $\geq 0.90$ & 0.940 & Fit \\
\hline
\end{tabular}

\subsection{Structural Model Assessment and Hypotheses Testing}

Instrument Validity is evaluated based on convergent validity and discriminant validity of the indicator calculated using Amos 22.0. Convergent validity is used to determine the validity of each relationship between indicators and their latent constructs (variables). Convergent validity parameters include 3 items, the value of item questionnaire loading ( $\geq 0.7)$, the value of Average Variance Extracted (AVE) with values ( $\geq 0.5$ ) and communally ( $\geq$ 0.5 ). (Convergent validity) is said to be high if the loading value is above 0.7 . Whereas discriminant validity is seen from the loading factor of each questionnaire item with the construct representing it $[22,25]$.

Reliable instruments are not necessarily valid, while valid instruments are generally reliable. Thus, the reliability testing of the instrument must be done because it is a requirement for testing the validity. In this connection, this study measures the reliability of data with internal consistency reliability. Internal consistent reliability testing is done by testing the instrument once, then to test the reliability of the data used indicator based on the formula Variance Extracted (AVE) and Construct Reliability (CR). And the indicator of the variable is said to be reliable if the AVE value is $\geq$ 0.05 and $C R \geq 0.07[22,25]$. Table 4 shows the results of Variance Extracted (AVE) and Construct Reliability (CR).

The process of testing this statistic can be seen in table 5. From the data processing, it is known that the CR value is related to showing values above 1.96 and below 0.05 for the value of $\mathrm{P}$ [26]. $\mathrm{H} 1, \mathrm{H} 2, \mathrm{H} 3, \mathrm{H} 4, \mathrm{H} 5$, and $\mathrm{H} 7$ support or significant (S), while H6 does not support or not significant (NS).

The findings of this study have significant implications for the intention to use mobile t-cash (e-money) payment system service in Yogyakarta. In this research use TAM model. The result of two technological characteristics of responsiveness and smartness in TCash mobile payments has a significant impact on perceived
Table 4: Standardized Item Loading, AVE, CR

\begin{tabular}{|c|c|c|c|c|}
\hline Variable & Item & $\begin{array}{c}\text { Factor } \\
\text { Loading }\end{array}$ & $\mathbf{C R}$ & AVE \\
\hline \multirow{3}{*}{ ITU } & ITU1 & 0.756 & \multirow{3}{*}{0.8334} & \multirow{3}{*}{0.6254} \\
\hline & ITU2 & 0.826 & & \\
\hline & ITU3 & 0.789 & & \\
\hline \multirow{3}{*}{ SEC } & SEC1 & 0.729 & \multirow{3}{*}{0.8344} & \multirow{3}{*}{0.6276} \\
\hline & SEC2 & 0.821 & & \\
\hline & SEC3 & 0.823 & & \\
\hline \multirow{3}{*}{ PU } & PU1 & 0.769 & \multirow{3}{*}{0.8567} & \multirow{3}{*}{0.6664} \\
\hline & PU2 & 0.868 & & \\
\hline & PU3 & 0.809 & & \\
\hline \multirow{3}{*}{ PEOU } & PEOU1 & 0.778 & \multirow{3}{*}{0.8670} & \multirow{3}{*}{0.6863} \\
\hline & PEOU2 & 0.777 & & \\
\hline & PEOU3 & 0.922 & & \\
\hline \multirow{3}{*}{ SMA } & SMA1 & 0.835 & \multirow{3}{*}{0.8584} & \multirow{3}{*}{0.6707} \\
\hline & SMA2 & 0.717 & & \\
\hline & SMA3 & 0.895 & & \\
\hline \multirow{3}{*}{ RES } & RES1 & 0.878 & \multirow{3}{*}{0.8474} & \multirow{3}{*}{0.6502} \\
\hline & RES2 & 0.758 & & \\
\hline & RES3 & 0.778 & & \\
\hline \multirow{5}{*}{ SI } & SI1 & 0.825 & \multirow{5}{*}{0.8737} & \multirow{5}{*}{0.5814} \\
\hline & SI2 & 0.718 & & \\
\hline & SI3 & 0.736 & & \\
\hline & SI4 & 0.712 & & \\
\hline & SI5 & 0.814 & & \\
\hline
\end{tabular}

Table 5: Hypothesis Test Results

\begin{tabular}{|l|c|c|c|c|c|c|}
\hline & Estimate & S.E. & C.R. & P & Label & Result \\
\hline PU $\leftarrow$ RES & .372 & .113 & 3.283 & .001 & par_13 & $\mathrm{S}$ \\
\hline PU $\leftarrow$ SMA & .192 & .090 & 2.142 & .032 & par_14 & $\mathrm{S}$ \\
\hline PU $\leftarrow$ PEOU & .277 & .089 & 3.111 & .002 & par_23 & $\mathrm{S}$ \\
\hline $\begin{array}{l}\text { ITU } \leftarrow \\
\text { PEOU }\end{array}$ & .293 & .118 & 2.477 & .013 & par_15 & $\mathrm{S}$ \\
\hline ITU $\leftarrow$ PU & .359 & .082 & 4.369 & $* * *$ & par_16 & $\mathrm{S}$ \\
\hline ITU $\leftarrow$ SI & -.063 & .078 & -.801 & .423 & par_21 & NS \\
\hline ITU $\leftarrow$ SEC & .382 & .130 & 2.936 & .003 & par_22 & S \\
\hline
\end{tabular}

usefulness. The results in this study support the results of previous studies conducted in [11], which ssuggest that responsiveness and smartness have a significant impact on perceived usefulness in mobile NFC payment services in Korea. The responsiveness and smartness presented in $\mathrm{t}$-cash bring a fast service to the consumer in around and small-sized form of NFC sticker. Transactions can be quickly and easily done by simply bringing the sticker to the sensor, then simply enter the pin, and the transaction is done, and make the customer look smarter by using the new model payment system presented by the mobile operator Telkomsel. With the innovation of a fast and unique shaped payment model will affect consumer interest to use t-cash (e-money).

Perceived ease of use has a significant effect on perceived usefulness, the results of which support the results of previous studies conducted in [15], which suggest that perceived ease of use has a significant impact on the perceived usefulness of mobile payments (IMMPA) for public transport. The perceived benefit of 
consumers towards the ease of using t-cash is to settle transactions in work and daily activities quickly. In [27], mentions if in a way perceived benefits by a consumer, the positive information from mouth to mouth can be spread widely through community forums and social media. So it is influential in increasing the intention of other consumers to use t-cash.

Perceived ease of use and perceived usefulness significantly influence intention to use. In This study support the results of previous studies conducted in [15], which in his research stated that perceived ease of use and perceived usefulness have a significant effect on intention to use mobile public transportation payment. In the use of t-cash is easy to learn in a short time to get used to the operation. Because the use of t-cash is very practical and efficient without the need to swipe like other e-money prepaid cards. Enough with tap sticker then the transaction is done. So in line with research [28], explaining that consumers will use ecommerce when a convenient technology is used easily and simply. So that easily t-cash to be used and perceived benefits in terms of effectiveness and quickly in the process of influential transactions in increasing the intention to use t-cash.

Security on T-Cash mobile payments has a significant impact on intention to use. in this study also supports the results of previous research, in [20], which in his research mentions that security has a significant effect on the intention to use mobile payment in the restaurant industry. In [29], it also reinforces that there is a positive relationship between security against intent to use mobile payment services. In transactions and their use, t-cash has a sufficiently secure and secure level of security. To activate tcash requires confirmation from active mobile phone number to fill out the identity and give notification of each transaction history of t-cash and matching between usage of operator card of Telkomsel and t-cash card number. And t-cash will ask for a pin of every transaction made. And in [30] explaining, security is a belief in a person that the activities of transactions conducted have a high enough level of security and all about the personal information provided is guaranteed and safeguarded. With the increase of security services provided to consumers, it is influential in the intention to use t-cash.

In social influence on intention to use cannot be accepted with a p-value greater than at the 0.05 level of significance. This finding explains that social environment factors around respondents such as friends, relatives, family, and community do not support or influence the respondent to use T-cash and in the use of T-cash will not improve the user's social status. The results of this study are different from previous studies that has been done in [19] which in his research stated that the influence of social or social influence significantly influences the intention to use a mobile credit card. In [31], it also shows there is a positive relationship of social influence factors on the intention to use ICT in teaching. In [32], the results show that social influences have a significant positive impact on the intentions of use for mobile data services. In $[33,34,35,36]$, also explains that social influences have a positive and significant influence on the use of SI. However, the results of this study are also supported by research [37], which finds that the influence of social factors on the interest of information systems utilization and social influencing factors on the use of information systems is rejected or has no effect. And the results of this study are also supported by interviews to some respondents who stated that using T-cash is encouraged by personal factors or self-interest that they feel the need to use T-cash, without any influence from friends or family.

In [38], explaining that a person's decision to choose a good and a service to be used will be influenced by several factors namely, environmental factors such as family, environment, culture, and personal factors. However, this research does not show any social influence which gives significant influence to the intention of using mobile t-cash (e-money) payment system service in Yogyakarta.

In [39], explaining factors that may affect purchasing behavior or intention to use are personal factors. Personal factors are psychologically someone who is not the same as others, therefore personal factors tend to have relatively consistent and long-lasting responses to environmental influences. In personal factors, there are characteristics: age and stage of the cycle, profession, economic situation, lifestyle, personality as well as self-concept [40]. Based on these characteristics that the differences in the results of this study can be caused by respondents who almost most of the profession are students and students. Which is the group of professions still rarely use t-cash facilities (e-money) because the profession does not have the intensity of payment transactions are too many, they choose to conduct transactions in cash or via atm. Personal factors are an important consideration in taking a decision other than environmental factors. So if the environment of the respondent has given the recommendation to use t-cash, the personal factor will become consumer consideration to determine consumer decision intention in using service of the mobile payment system of t-cash (e-money) in the future $[41,42]$.

\section{Conclusion}

In this study found that, with respect to the intention to use mobile payment service system T-cash in Yogyakarta. Technological factors characteristic of responsiveness and smartness have a significant effect on perceived usefulness, perceived ease of use also shows significant relation to perceived usefulness. In perceived ease of use and perceived usefulness have a significant effect on the intention to use. The security factor also has a significant effect on the intention to use. With the conclusion of H1, H2, H3, H4, H5, and H7 are supported or accepted. Only one factor is social influence has no relationship to the intention to use. So, H6 is neither support nor rejected. That way social influencing factors will become less important than personal factors that ultimately are a consideration and consumer decisions to use them.

This study also shows that perceived usefulness, security and efficiency are important factors. The interview results concluded that for those who have never used e-money before will be a little confused how to use this service, and what benefits they get. This is due to a lack of knowledge about mobile payments [43]. So the challenge for the company is to develop and create new perceptions about consumer lifestyles in the use of T-cash, where T-cash can make the payment system easier, convenient to use and become the trend of payment, and better explain what happened and need to be done during the T-cash mobile payment process. by doing this may have an effect on the intention to use T-cash [29].

Based on the conclusions obtained from the results of the analysis in this study, researchers provide suggestions for further 
research, the suggestion is expected by researchers to review research at this time and previous research by adding or using other variables not contained in this study. So it can be further known what factors can affect a person to use new technologies such as emoney products in this study. subsequent research can also use a sample with a larger number, and also increase the number of indicators of the variables for the results of research can be obtained more optimal.

\section{Acknowledgment}

I would like to thank my supervisor for his guidance on this paper and to Universitas Atma Jaya Yogyakarta, Yogyakarta, Indonesia.

\section{References}

[1] I. Mackensen, "Mobile Payments - A Strategic Forecasting Approach -," 2015.

[2] F. Liébana-Cabanillas, J. Sánchez-Fernández, and F. Muñoz-Leiva, "The moderating effect of experience in the adoption of mobile payment tools in Virtual Social Networks: The m-Payment Acceptance Model in Virtual Social Networks (MPAM-VSN)," Int. J. Inf. Manage., 2014.

[3] F. José Liébana-Cabanillas Juan Sánchez-Fernández Francisco MuñozLeiva et al., "Industrial Management \& Data Systems Role of gender on acceptance of mobile payment," Ind. Manag. Data Syst. Internet Res. Ind. Manag. \&amp Data Syst. Iss Tao Zhou Ind. Manag. \&amp Data Syst., vol. 114, no. 6, pp. 369-392, 2014.

[4] L.-C. Francisco, M.-L. Francisco, and S.-F. Juan, "Payment Systems in New Electronic Environments: Consumer Behavior in Payment Systems via SMS," 2015.

[5] K. Pousttchi and D. G. Wiedemann, "What_influences_consumers_intention_to_use_mobile," 2014.

[6] H. Khatimah and F. Halim, "The effect of attitude and its decomposed, perceived behavioral control and its decomposed and awareness on intention to use e-money mobile in Indonesia," J. Sci. Res. Dev., 2016.

[7] T. J. Gerpott and K. Kornmeier, "Determinants of customer acceptance of mobile payment systems," Int. J. Electron. Financ., 2009.

[8] D. Flood, T. West, and D. Wheadon, "Trends in Mobile Payments in Developing and Advanced Economies," 2013.

[9] M. S. Arifin et al., "Smart Vending Machine Based on SMS Gateway For General Transactions," IEEE, 2017.

[10] S. Megadewandanu, Suyoto, and Pranowo, "Exploring mobile wallet adoption in Indonesia using UTAUT2: An approach from consumer perspective," in Proceedings - 2016 2nd International Conference on Science and Technology-Computer, ICST 2016, 2017.

[11] S. Shin, "The Effects Of Technology Readiness And Technology Acceptance On NFC Mobile Payment Services In Korea," J. Appl. Bus. Res., vol. 30 , no. 6 .

[12] P. Moses, S. L. Wong, K. A. Bakar, and R. Mahmud, "Perceived Usefulness and Perceived Ease of Use: Antecedents of Attitude Towards Laptop Use Among Science and Mathematics Teachers in Malaysia," Asia-Pacific Educ. Res., 2013.

[13] F. D. Davis, "Perceived Usefulness, Perceived Ease of Use, and User Acceptance of Information Technology," Source MIS Q., vol. 13, no. 3, pp. 319-340, 1989.

[14] R. Rauniar, G. Rawski, J. Yang, and B. Johnson, “Technology acceptance model (TAM) and social media usage: an empirical study on Facebook," $J$. Enterp. Inf. Manag., 2014.

[15] L. Di Pietro, R. Guglielmetti Mugion, G. Mattia, M. Renzi, and M. Toni, "The Integrated Model on Mobile Payment Acceptance (IMMPA): An empirical application to public transport," Transp. Res. Part C, vol. 56, pp. 463-479, 2015.

[16] E. Shih, -Tse Wang, N. Pei, and -Yu Chou, "Consumer Characteristics, Social Influence, and System Factors on Online Group-Buying Repurchasing Intention,” J. Electron. Commer. Res., vol. 15, no. 2, 2014.

[17] G. Harvey Tanakinjal, R. MacDonell Andrias, S. Laison Sondoh Jr, and A. Asri Ag Ibrahim, "Relationship between Perceived Benefits and Social Influence towards Self- Disclosure and Behavioral Intention in Web 2.0," Eur. J. Bus. Soc. Sci., vol. 1, no. 4, pp. 63-75, 2012.

[18] D. B. Setyohadi, M. Aristian, B. L. Sinaga, and N. A. A. Hamid, "Social critical factors affecting intentions and behaviours to use E-Learning: An empirical investigation using technology acceptance model," Asian J. Sci.
Res., 2017.

[19] G. W. H. Tan, K. B. Ooi, S. C. Chong, and T. S. Hew, "NFC mobile credit card: The next frontier of mobile payment?," Telemat. Informatics, 2014.

[20] C. Cobanoglu, W. Yang, A. Shatskikh, and A. Agarwal, "Hospitality Review Are Consumers Ready for Mobile Payment? An Examination of Consumer Acceptance of Mobile Payment Technology in Restaurant Industry "Are Consumers Ready for Mobile Payment? An," 2015.

[21] A. Raman and V. Annamalai, "Web Services and e-Shopping Decisions: A Study on Malaysian e-Consumer," IJCA Spec. Issue "Wireless Inf. Networks Bus. Inf. Syst., 2011.

[22] T. Wijaya, Analisis Structural Equation Modeling Menggunakan AMOS, 5 ed. Yogyakarta: Universitas Atma Jaya Yogyakarta, 2009.

[23] J. W. Creswell, "Research Design: Qualitative, Quantitative, and Mixed Methods Approaches," Can. J. Univ. Contin. Educ., vol. 35, no. 2, 2009.

[24] A. Ferdinand, Structural Equation Modelling dalam Penelitian Manajemen. Semarang: FE UNDIP, 2002.

[25] R. B. Kline, Principles and Practice of Structural Equation Modeling, 3rd ED. New York: Guilford Press, 2011.

[26] J. f Hair Jr, W. C. Black, B. J. Babin, and R. E. Anderson, "Multivariate Data Analysis, 7/e," Pearson Prentice Hall, 2010.

[27] J. C. Roca et al., "Information Management \& Computer Security The importance of perceived trust, security and privacy in online trading systems 'The importance of perceived trust, security and privacy in online trading systems' The importance of perceived trust, security and privacy in online trading systems," Inf. Manag. Comput. Secur. Ind. Manag. \&amp; Data Syst. Online Inf. Rev. Iss Downloaded by MAHIDOL Univ., vol. 17, no. 22, pp. 96-113, 2015.

[28] M. Bonera, "The propensity of e-commerce usage: the influencing variables," Manag. Res. Rev., 2011.

[29] J. Hauff, "Consumer Acceptance of Mobile Payment Services," 2011.

[30] C. L. Hsu, C. F. Wang, and J. C. C. Lin, "Investigating customer adoption behaviours in Mobile Financial Services," Int. J. Mob. Commun., 2011.

[31] S. M. Salleh and K. Laxman, "Investigating the factors influencing teachers' use of ICT in teaching in Bruneian secondary schools," Educ. Inf. Technol., 2013.

[32] T. Faziharudean and T. Li-Ly, "Consumers' behavioral intentions to use mobile data services in Malaysia," African J. Bus. Manag., vol. 5, no. 5, pp. 1811-1821, 2011.

[33] R. L. Thompson, C. A. Higgins, and J. M. Howell, "Personal Computing: Toward a Conceptual Model of Utilization," MIS Q., 1991.

[34] V. Venkatesh and F. D. Davis, "A Theoretical Extension of the Technology Acceptance Model: Four Longitudinal Field Studies," Manage. Sci., vol. 46, no. 2, pp. 186-204, 2000.

[35] G. C. Moore and I. Benbasat, "Development of an instrument to measure the perceptions of adopting an information technology innovation," Inf. Syst. Res., 1991.

[36] V. Venkatesh, M. G. Morris, G. B. Davis, and F. D. Davis, "User Acceptance of Information Technology: Toward a Unified View," vol. 27, no. 3, pp. 425-478, 2003.

[37] D. P. Triadmojo, "Analysis Of Factors Affecting The Interests Of The Use Of Information Systems And Use Of Information Systems (Empirical Study On Government Of Banyuwangi)," 2016.

[38] F. Liébana-Cabanillas, J. Sánchez-Fernández, and F. Muñoz-Leiva, "Antecedents of the adoption of the new mobile payment systems: The moderating effect of age," Comput. Human Behav., 2014.

[39] Kotler and Philip, Manajemen Pemasaran, Edisi 11. Jakarta: PT Indeks Kelompok Gramedia, 2005.

[40] Kotler, Philip, and G. Amstrong, Principles of Marketing. New Jersey: Person Education, 2012.

[41] S. Y. Park, M.-W. Nam, and S.-B. Cha, "University students' behavioral intention to use mobile learning: Evaluating the technology acceptance model," Br. J. Educ. Technol., 2012.

[42] W. Nasri and L. Charfeddine, "Factors affecting the adoption of Internet banking in Tunisia: An integration theory of acceptance model and theory of planned behavior," J. High Technol. Manag. Res., 2012.

[43] A. S. Etim, "Mobile banking and mobile money adoption for financial inclusion,” Res. Bus. Econ. JournalBold Rotman, vol. 9, 2014. 